\title{
Clinical patterns in asthma based on proximal and distal airway nitric oxide categories
}

\author{
James L Puckett ${ }^{+1}$, Richard WE Taylor ${ }^{\dagger 1}$, Szu-Yun Leu ${ }^{+2}$, Olga L Guijon ${ }^{+3}$, Anna S Aledia ${ }^{+1,4}$, Stanley P Galant ${ }^{+3}$ and \\ Steven C George*+1,5
}

\begin{abstract}
Background: The exhaled nitric oxide (eNO) signal is a marker of inflammation, and can be partitioned into proximal $\left[J^{\prime} \mathrm{w}_{\mathrm{NO}}(\mathrm{nl} / \mathrm{s})\right.$, maximum airway flux] and distal contributions [CA $\mathrm{NO}_{\mathrm{NO}}(\mathrm{ppb})$, distal airway/alveolar NO concentration]. We hypothesized that J'aw ${ }_{N O}$ and $C A_{N O}$ are selectively elevated in asthmatics, permitting identification of four inflammatory categories with distinct clinical features.

Methods: In 200 consecutive children with asthma, and 21 non-asthmatic, non-atopic controls, we measured baseline spirometry, bronchodilator response, asthma control and morbidity, atopic status, use of inhaled corticosteroids, and eNO at multiple flows $(50,100$, and $200 \mathrm{ml} / \mathrm{s})$ in a cross-sectional study design. A trumpet-shaped axial diffusion model of NO exchange was used to characterize J'aw $\mathrm{w}_{\mathrm{NO}}$ and $\mathrm{CA}_{\mathrm{NO}}$.

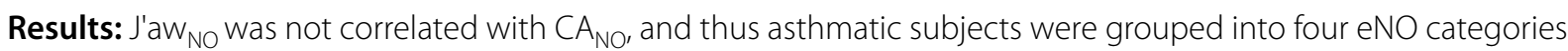
based on upper limit thresholds of non-asthmatics for J'aw ${ }_{N O}(\geq 1.5 \mathrm{nl} / \mathrm{s})$ and $C A_{N O}(\geq 2.3 \mathrm{ppb})$ : Type I (normal J'aw no $_{N O}$ and $\left(A_{N O}\right)$, Type II (elevated J'aw $w_{N O}$ and normal $C A_{N O}$ ), Type III (elevated J'aw $w_{N O}$ and $C A_{N O}$ ) and Type IV (normal J'aw and elevated $\left(A_{N O}\right)$. The rate of inhaled corticosteroid use (lowest in Type III) and atopy (highest in Type II) varied significantly amongst the categories influencing J'aw $\mathrm{W}_{\mathrm{NO}}$, but was not related to $\mathrm{CA}_{\mathrm{NO}}$, asthma control or morbidity. All categories demonstrated normal to near-normal baseline spirometry; however, only eNO categories with increased $\mathrm{CA}_{\mathrm{NO}}$ (III and IV) had significantly worse asthma control and morbidity when compared to categories I and II.

Conclusions: $J^{\prime} a w_{N O}$ and $C_{N}$ reveal inflammatory categories in children with asthma that have distinct clinical features including sensitivity to inhaled corticosteroids and atopy. Only categories with increase $\mathrm{CA}_{\mathrm{NO}}$ were related to poor asthma control and morbidity independent of baseline spirometry, bronchodilator response, atopic status, or use of inhaled corticosteroids.
\end{abstract}

\section{Background}

Asthma is a complex disease characterized by inflammation throughout the respiratory tract from the large airways to the alveoli [1-3]. Moreover, there is mounting evidence that asthma control is correlated with the extent of inflammation, such that symptoms are worse when the inflammation reaches the more peripheral lung compartments [2-6]. One of the great challenges in asthma research is to develop minimally invasive approaches,

\footnotetext{
*Correspondence: scgeorge@uci.edu

1 Department of Biomedical Engineering, 2420 Engineering Tower, University of California, Irvine, Irvine, CA 92697, USA

+ Contributed equally

Full list of author information is available at the end of the article
}

particularly in children, that could assess the site and extent of inflammation. Such tools could enhance our understanding of the mechanisms that characterize asthma, and prove useful in choosing appropriate therapies [7].

There is mounting data that analysis of exhaled nitric oxide (eNO) could serve as a non-invasive indicator of the extent and site of inflammation in asthma. eNO is a flow dependent signal $[8,9]$, and current guidelines [10] stipulate an exhalation flow of $50 \mathrm{ml} / \mathrm{s}\left(\mathrm{FE}_{\mathrm{NO}, 50}\right) . \mathrm{FE}_{\mathrm{NO}, 50}$ is purported to be a marker of airway inflammation, since it is elevated in steroid naïve asthmatics [11], reduced upon administration of anti-inflammatory medications [12], and is correlated with biological [13-15] and physiological 
[16-18] markers of airway inflammation. However, some patients may fulfill the criteria for the diagnosis of asthma, and yet $\mathrm{FE}_{\mathrm{NO}, 50}$ levels will be normal [19]. Numerous longitudinal studies have investigated the use of $\mathrm{FE}_{\mathrm{NO}, 50}$ as a tool in the clinical management of asthma [20-27]. The results of these studies have been mixed, as four of the studies demonstrated that $\mathrm{FE}_{\mathrm{NO}, 50}$ was of limited use in managing asthmatic symptoms and corticosteroid dose [20,23,24,26]; however, methodological issues in the design of these studies have been raised [28]. Therefore, despite the undeniable link between NO and inflammation, the promise of $\mathrm{FE}_{\mathrm{NO}, 50}$ as a surrogate marker of airway inflammation has yet to be fulfilled, and an alternate approach may be indicated [29].

eNO can be partitioned into proximal airway [J'aw ${ }_{\mathrm{NO}}$ (nl/s), maximum airway flux, generations 1-16] and distal airway/alveolar contributions $\left[\mathrm{CA}_{\mathrm{NO}}(\mathrm{ppb})\right.$, alveolar $\mathrm{NO}$ concentration, generations 17-23] (Fig. 1A). Increased $\mathrm{J}^{\prime} \mathrm{aw}_{\mathrm{NO}}$ with normal $\mathrm{CA}_{\mathrm{NO}}$ has been reported in adults [30] and children [6] with mild asthma, whereas $\mathrm{CA}_{\mathrm{NO}}$ has been reported to be increased in asthmatics with poor control [5], enhanced symptoms [31], more severe

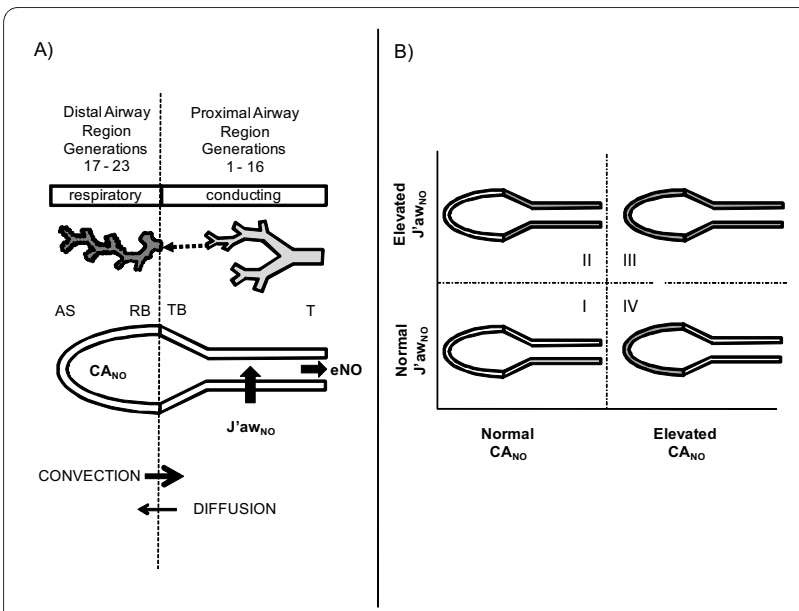

Figure 1 Schematic of two-compartment model and four eNO categories. A) During exhalation of nitric oxide (eNO), a steady state mean distal airway/alveolar concentration $\left(\mathrm{CA}_{\mathrm{NO}}, \mathrm{ppb}\right)$ enters the conducting airway compartment (net transfer is convection minus diffusion) where upon additional $\mathrm{NO}$ is transferred from the proximal airway walls (J'aw $\left.\mathrm{NO}_{\mathrm{NO}}, \mathrm{nl} / \mathrm{s}\right)$. $\mathrm{CA}_{\mathrm{NO}}$ represents the respiratory region of the lungs (Weibel generations 17-23). J'aw NO $_{\text {No }}$ represents the larger conducting airway region of the lungs (Weibel generations 1-16), and considers the increasing surface area per unit volume of the airway tree (i.e., trumpet shape). T: trachea; TB: terminal bronchiole; RB: respiratory bronchiole; AS: alveolar sac]. B) J'aw $\mathrm{N}_{\mathrm{NO}}$ and $\mathrm{CA}_{\mathrm{NO}}$ can be selectively elevated (thick gray shading) and may independently characterize proximal and distal lung inflammation, creating four eNO categories: Type I, normal J'aw $\mathrm{NO}_{\mathrm{NO}}$ and normal $\mathrm{CA}_{\mathrm{NO}}$; Type II, elevated J'aw $\mathrm{N}_{\mathrm{NO}}$ and normal $\mathrm{CA}_{\mathrm{NO}}$; Type III, elevated J'aw $\mathrm{w}_{\mathrm{NO}}$ and elevated $\mathrm{CA}_{\mathrm{NO}}$; and Type IV, normal $J^{\prime} \mathrm{WW}_{\mathrm{NO}}$ and elevated $\mathrm{CA}_{\mathrm{NO}}$. disease [32], and be a predictor of asthma exacerbation in adults [33]. These findings suggest that $\mathrm{J}^{\prime} \mathrm{aw}_{\mathrm{NO}}$ and $\mathrm{CA}_{\mathrm{NO}}$ may be selectively increased and thus independently characterize proximal and distal lung inflammation (Fig. $1 B)$. Hence, we hypothesized that $\mathrm{J}^{\prime} \mathrm{aw}_{\mathrm{NO}}$ and $\mathrm{CA}_{\mathrm{NO}}$ can be selectively elevated in children with asthma, creating four eNO categories, characterized by distinct clinical features.

\section{Methods}

\section{Study participants}

Two hundred pediatric patients with signs and symptoms of asthma within the past three months who presented to the Children's Hospital of Orange County (CHOC) Breathmobile, a mobile asthma clinic staffed with asthma specialists, for an asthma evaluation participated in the cross-sectional study. Criteria for the diagnosis of asthma included a previous history of recurrent coughing, wheezing, shortness of breath (at rest or following exercise), and symptomatic improvement following short acting bronchodilator [1]. Patients were included and considered steroid naive if they reported no use of inhaled corticosteroid (ICS) in the past 8 weeks, or considered steroid treated if they have reported compliance with prescribed ICS therapy based on NAEPP (National Asthma Education and Prevention Program) guidelines over the previous 8 weeks. Patients were excluded from the study if they had any other heart or lung disease, any smoking within the past five years, or they were ICS treated for less than 8 weeks. Short and long acting $\beta_{2}$ agonists were withheld for 12 hours prior to the study. Additionally, twenty-one non-asthmatic non-atopic children were enrolled in the study. Each subject and their guardian completed the informed consent documents which had been approved by the University of California, Irvine and $\mathrm{CHOC}$ Institutional Review Boards.

\section{Measurements}

Asthma symptoms were quantified using the validated Asthma Control Test (ACT) for children (age 6 - 11 years) [34] and adults (age 12 - 17 years) [35]. Retrospective data on asthma risk factors were collected by the physician. These included severe attacks (exacerbation requiring increased use of albuterol and short-term oral corticosteroids when available), emergency department visits, or hospitalizations within the preceding 8 weeks. Skin prick tests for common allergens (cat, dog, feathers, cockroach, dust mites, mold, weeds, trees and grasses) were performed, and the participant was considered atopic if positive to at least one antigen.

The eNO measurements at multiple flows $(50 \mathrm{ml} / \mathrm{s}, 100$ $\mathrm{ml} / \mathrm{s}$ and $200 \mathrm{ml} / \mathrm{s}$; NIOX Flex, Aerocrine Ltd, Stockholm, Sweden) were performed prior to the pre-bronchodilator spirometric maneuver. eNO measurements at all three 
flows were performed in triplicate in accordance with ATS guidelines [10], and the order of the nine maneuvers randomized. The physicians did not have access to eNO data at any time; hence clinical management was based solely on history and spirometry.

Standard spirometry was performed (WinDx Spirometer, Creative Biomedics International, $\mathrm{CA}$ ) in accordance with ATS criteria [36]. To determine the bronchodilator response (BDR), albuterol (180 mcg; 2 puff with spacer) was administered and spirometry was repeated $10 \mathrm{~min}$ utes later. The BDR was calculated as the percent change in $\mathrm{FEV}_{1}$ following administration of albuterol.

\section{Calculation of $\mathrm{J}^{\prime} \mathrm{aw}_{\mathrm{NO}}$ and $\mathrm{CA}_{\mathrm{NO}}$}

The average eNO concentration at each flow was calculated following current ATS guidelines [10]. Utilizing a trumpet-shaped model of NO exchange that accounts for axial diffusion [37], we applied a linear least squares analysis to a plot of the average NO elimination rate (product of average exhaled NO and average flow) versus the average exhalation flow to estimate $\mathrm{J}^{\prime} \mathrm{aw}_{\mathrm{NO}}$ and $\mathrm{CA}_{\mathrm{NO}}$ [38].

\section{Statistical analysis}

Spearman rank-order correlation was first evaluated among eNO measurements to evaluate the relationships between $\mathrm{FE}_{\mathrm{NO}}$, J'aw $\mathrm{NO}_{\mathrm{NO}}$ and $\mathrm{CA}_{\mathrm{NO}}$, and the asthmatic subjects were further categorized into four categories based on $\mathrm{J}^{\prime} \mathrm{aw}_{\mathrm{NO}}$ and $\mathrm{CA}_{\mathrm{NO}}$. Clinical features were compared among the four categories and with the non-asthmatic controls using the Kruskal-Wallis test and the MantelHaenszel chi-square test. For variables with significant differences among the groups, paired comparisons were applied with Bonferroni's multiple comparison adjustment. Data are reported using median and range (minimum-maximum), or number of subjects and proportion. Significance level was set at 0.05 , and analysis was performed using SAS 9 (Cary, NC).

\section{Results}

In both asthmatic and non-asthmatic populations, $95 \%$ of the participants reported an ethnicity of Hispanic. All of the enrolled subjects were able to perform the exhaled $\mathrm{NO}$ and spirometric maneuvers. However, among the asthmatic subjects, one was excluded due to missing spirometric data, and twenty were excluded from the analysis since their eNO at multiple exhalation flows did not fit the linear model of NO exchange; this was due to a negative estimated $\mathrm{CA}_{\mathrm{NO}}$ (i.e., non-physiologic interpretation). General features of the entire asthma population are summarized in the first column of Table 1. Our group of asthmatic children was generally mild and well-controlled (median ACT score of 21) with normal baseline spirometry (median $\mathrm{FEV}_{1} / \mathrm{FVC}=87.0$ ).

\section{$\mathrm{FE}_{\mathrm{NO}, 50}, \mathrm{~J}^{\prime} \mathrm{aw}_{\mathrm{NO}}$, and $\mathrm{CA}_{\mathrm{NO}}$ in non-asthmatic control group} In the non-asthmatic non-atopic children, the median and range of $\mathrm{FE}_{\mathrm{NO}, 50}, \mathrm{~J}^{\prime} \mathrm{aw}_{\mathrm{NO}}$ and $\mathrm{CA}_{\mathrm{NO}}$ were found to be $8.5(2.2-15.3), 0.67(0.13-1.44) \mathrm{nl} / \mathrm{s}$, and $1.47(0.1-2.23)$ $\mathrm{ppb}$, respectively (Table 1 ). Based on this distribution, and rounding up the maximum value to two significant digits produces a conservative estimate of a threshold for elevated $\mathrm{FE}_{\mathrm{NO}, 50}$, proximal airway $\mathrm{NO}$, and distal airway/ alveolar NO: $\mathrm{FE}_{\mathrm{NO}, 50} \geq 16 \mathrm{ppb}, \mathrm{J}^{\prime} \mathrm{aw}_{\mathrm{NO}} \geq 1.5 \mathrm{nl} / \mathrm{s}$ and $\mathrm{CA}_{\mathrm{NO}}$ $\geq 2.3 \mathrm{ppb}$. The results for J'aw ${ }_{\mathrm{NO}}$ and $\mathrm{CA}_{\mathrm{NO}}$ are similar to the findings of other reports using the two compartment model [39] to partition exhaled NO in non-asthmatic children when axial diffusion is considered $[5,40]$.

\section{Correlations among $\mathrm{FE}_{\mathrm{NO}}$ and regional nitric oxide parameters}

In the asthmatic subjects, $\mathrm{J}^{\prime} \mathrm{aw}_{\mathrm{NO}}$ is strongly correlated with $\mathrm{FE}_{\mathrm{NO}, 50}(\mathrm{r}=0.99), \mathrm{FE}_{\mathrm{NO}, 100}(\mathrm{r}=0.93)$ and $\mathrm{FE}_{\mathrm{NO}, 200}(\mathrm{r}=$ 0.95). $\mathrm{CA}_{\mathrm{NO}}$ is not correlated with $\mathrm{FE}_{\mathrm{NO}, 50}(\mathrm{r}=0.09)$ or $\mathrm{FE}_{\mathrm{NO}, 100}(\mathrm{r}=0.11)$. At the highest flow of $200 \mathrm{ml} / \mathrm{s}$, the contribution of the proximal airways is reduced, but $\mathrm{CA}_{\mathrm{NO}}$ is only very weakly correlated $(r=0.23)$ with $\mathrm{FE}_{\mathrm{NO}, 200}$.

\section{Exhaled nitric oxide (eNO) categories}

$\mathrm{CA}_{\mathrm{NO}}$ and $\mathrm{J}^{\prime} \mathrm{aw}_{\mathrm{NO}}$ are not correlated $(\mathrm{r}=-0.002)$ indicating that they provide independent information. Hence, asthmatic subjects were classified into four eNO categories (Fig. 2) based on the upper limit of non-asthmatic thresholds for J'aw ${ }_{\mathrm{NO}}(\geq 1.5 \mathrm{nl} / \mathrm{s})$ and $\mathrm{CA}_{\mathrm{NO}}(\geq 2.3 \mathrm{ppb})$ :

Type I: J'aw ${ }_{\mathrm{NO}}$ and $\mathrm{CA}_{\mathrm{NO}}$ not elevated; $\mathrm{n}=67,(37 \%)$

Type II: elevated J'aw ${ }_{\mathrm{NO}} ; \mathrm{n}=66,(37 \%)$

Type III: elevated J'aw ${ }_{\mathrm{NO}}$ and elevated $\mathrm{CA}_{\mathrm{NO}} ; \mathrm{n}=27$, (15\%)

Type IV: elevated $\mathrm{CA}_{\mathrm{NO}} ; \mathrm{n}=19,(11 \%)$

There were no gender or age differences amongst the four eNO categories and the non-asthmatic controls (Table 1). The proportion of atopic subjects was significantly different between the groups $(\mathrm{p}=0.0001$, Table 1$)$, where Type II had significantly higher rates compared to Type I and Type IV.

Based on patient history, inhaled corticosteroid (ICS) naïve was defined as no oral or ICS within the last 8 weeks and ICS treated was defined as prescribed ICS treatment for at least 8 weeks. Significant differences $(\mathrm{p}<$ 0.0001 , Table 1) existed between the eNO categories with respect to ICS use. The proportion of subjects who were ICS treated was significantly less in Type III when compared to the other eNO categories and was significantly less in Type II compared to Type I.

As defined above, J'aw ${ }_{\mathrm{NO}}$ was elevated in Type II [3.0 $(1.6-17.0) \mathrm{nl} / \mathrm{s}]$ and Type III [3.5 (1.5-13.7) $\mathrm{nl} / \mathrm{s}]$ but not in 
Table 1: Clinical data and risk factors for the exhaled nitric oxide categories

\begin{tabular}{|c|c|c|c|c|c|c|c|c|}
\hline & $\begin{array}{c}\text { All } \\
\text { asthmatics } \\
(n=179)\end{array}$ & $\begin{array}{c}\text { Non-asthmatic } \\
(\mathbf{n}=\mathbf{2 1})\end{array}$ & $\begin{array}{c}\text { Type I } \\
\text { Normal Nitric } \\
\text { Oxide } \\
(n=67)\end{array}$ & $\begin{array}{l}\text { Type II } \\
\text { Proximal Airway } \\
\text { Predominant } \\
(n=66)\end{array}$ & $\begin{array}{c}\text { Type III } \\
\text { Proximal and Distal } \\
\text { Airway Predominant } \\
(\mathrm{n}=\mathbf{2 7})\end{array}$ & $\begin{array}{l}\text { Type IV } \\
\text { Distal Airway } \\
\text { Predominant } \\
\quad(n=19)\end{array}$ & $\begin{array}{l}\text { Overall test } \\
\text { p-value\# }\end{array}$ & $\begin{array}{l}\text { Paired compar- } \\
\text { ison result\$ }\end{array}$ \\
\hline \multicolumn{9}{|c|}{ DEMOGRAPHICS } \\
\hline Age & $\begin{array}{c}10 \\
(6-17)\end{array}$ & $\begin{array}{c}10 \\
(6-17)\end{array}$ & $\begin{array}{c}10 \\
(6-17)\end{array}$ & $\begin{array}{c}11 \\
(6-17)\end{array}$ & $\begin{array}{c}11 \\
(6-16)\end{array}$ & $\begin{array}{c}11 \\
(6-17)\end{array}$ & 0.13 & ---- \\
\hline $\begin{array}{l}\text { Gender } \\
\text { Male }\end{array}$ & $\begin{array}{c}117 \\
(65 \%)\end{array}$ & $\begin{array}{c}12 \\
(57 \%)\end{array}$ & $\begin{array}{c}48 \\
(72 \%)\end{array}$ & $\begin{array}{c}44 \\
(67 \%)\end{array}$ & $\begin{array}{c}16 \\
(59 \%)\end{array}$ & $\begin{array}{c}9 \\
(47 \%)\end{array}$ & 0.30 & ---- \\
\hline Atopy & $\begin{array}{c}143 \\
(80 \%)\end{array}$ & $\begin{array}{c}0 \\
(0 \%)\end{array}$ & $\begin{array}{c}44 \\
(66 \%)\end{array}$ & $\begin{array}{c}62 \\
(94 \%)\end{array}$ & $\begin{array}{c}23 \\
(89 \%)\end{array}$ & $\begin{array}{c}12 \\
(63 \%)\end{array}$ & 0.0001 & II $>$ I, IV \\
\hline $\begin{array}{c}\text { ICS } \\
\text { treatment }\end{array}$ & $\begin{array}{c}110 \\
(61 \%)\end{array}$ & ---- & $\begin{array}{c}53 \\
(79 \%)\end{array}$ & $\begin{array}{c}37 \\
(56 \%)\end{array}$ & $\begin{array}{c}5 \\
(18 \%)\end{array}$ & $\begin{array}{c}15 \\
(79 \%)\end{array}$ & $<0.0001$ & $\begin{array}{c}\| \mathrm{II}<\mathrm{I}, \mathrm{II}, \mathrm{IV} \\
\|<1\end{array}$ \\
\hline \multicolumn{9}{|c|}{ EXHALED NITRIC OXIDE } \\
\hline $\mathrm{FE}_{\mathrm{NO}, 50}$ & $\begin{array}{c}19.6 \\
(3.7-186)\end{array}$ & $\begin{array}{c}8.5 \\
(2.2-15.3)\end{array}$ & $\begin{array}{c}9.4 \\
(3.7-18.4)\end{array}$ & $\begin{array}{c}33.4 \\
(17.7-186)\end{array}$ & $\begin{array}{c}49.9 \\
(22.3-159)\end{array}$ & $\begin{array}{c}8.5 \\
(4.6-16.9)\end{array}$ & 0.0001 & $\begin{array}{c}\| I, I I I>N C, I, I V \\
I I I>I I\end{array}$ \\
\hline $\mathrm{J}^{\prime a w_{N O}}(\mathrm{nl} / \mathrm{s})$ & $\begin{array}{c}1.6 \\
(0.1-17)\end{array}$ & $\begin{array}{c}0.7 \\
(0.1-1.4)\end{array}$ & $\begin{array}{c}0.7 \\
(0.1-1.5)\end{array}$ & $\begin{array}{c}3.0 \\
(1.6-17)\end{array}$ & $\begin{array}{c}3.5 \\
(1.5-13.7)\end{array}$ & $\begin{array}{c}0.5 \\
(0.1-1.3)\end{array}$ & 0.0001 & $\mathrm{II}, \mathrm{III}>\mathrm{NC}, \mathrm{I}, \mathrm{IV}$ \\
\hline $\mathrm{CA}_{\mathrm{NO}}(\mathrm{ppb})$ & $\begin{array}{c}1.3 \\
(0.1-13.4)\end{array}$ & $\begin{array}{c}1.5 \\
(0.1-2.2)\end{array}$ & $\begin{array}{c}1.0 \\
(0.006-2.3)\end{array}$ & $\begin{array}{c}0.8 \\
(0.02-2.2)\end{array}$ & $\begin{array}{c}3.8 \\
(2.4-13.4)\end{array}$ & $\begin{array}{c}3.1 \\
(2.3-5.1)\end{array}$ & 0.0001 & $\begin{array}{c}\text { III, IV }>N C, I, I I \\
I I I>I V\end{array}$ \\
\hline \multicolumn{9}{|c|}{ CONTROL and MORBIDITY } \\
\hline $\mathrm{FEV}_{1} / \mathrm{FVC}$ & $\begin{array}{c}87.0 \\
(70.4-102.1)\end{array}$ & $\begin{array}{c}89.6 \\
(84.5-102.1)\end{array}$ & $\begin{array}{c}89.4 \\
(71.7-100)\end{array}$ & $\begin{array}{c}85.5 \\
(70.4-101)\end{array}$ & $\begin{array}{c}83.3 \\
(72-100.1)\end{array}$ & $\begin{array}{c}87.8 \\
(80.7-100.7)\end{array}$ & 0.0016 & $\mathrm{III}<\mathrm{I}, \mathrm{NC}$ \\
\hline $\mathrm{FEV}_{1}(\%)$ & $\begin{array}{c}106 \\
(67.1-149)\end{array}$ & $\begin{array}{c}106 \\
(92.6-118)\end{array}$ & $\begin{array}{c}108 \\
(75.1-149)\end{array}$ & $\begin{array}{c}105 \\
(67.1-149)\end{array}$ & $\begin{array}{c}106 \\
(76.2-132)\end{array}$ & $\begin{array}{c}103 \\
(77.9-127)\end{array}$ & 0.68 & ---- \\
\hline BDR & $\begin{array}{c}6.3 \\
(0-35.5) \\
{[n=167]}\end{array}$ & $\begin{array}{c}5.3 \\
(0.6-6.6) \\
{[n=13]}\end{array}$ & $\begin{array}{c}4.1 \\
(0-13.8) \\
{[n=63]}\end{array}$ & $\begin{array}{c}7.0 \\
(0-27.4) \\
{[n=60]}\end{array}$ & $\begin{array}{c}10.1 \\
(0.7-35.5) \\
{[n=26]}\end{array}$ & $\begin{array}{c}5.0 \\
(0.7-10.6) \\
{[n=18]}\end{array}$ & $<0.0001$ & $\begin{array}{c}\|>1 \\
\text { III>NC, I, IV }\end{array}$ \\
\hline $\mathrm{ACT}$ & $\begin{array}{c}21 \\
(10-27)\end{array}$ & ---- & $\begin{array}{c}23 \\
(17-27)\end{array}$ & $\begin{array}{c}22 \\
(17-26)\end{array}$ & $\begin{array}{c}17 \\
(10-23)\end{array}$ & $\begin{array}{c}17 \\
(10-24)\end{array}$ & $<0.0001$ & III, IV <I, II \\
\hline Morbidity* & $\begin{array}{c}26 \\
(15 \%)\end{array}$ & ---- & $\begin{array}{c}8 \\
(12 \%)\end{array}$ & $\begin{array}{c}3 \\
(4.5 \%)\end{array}$ & $\begin{array}{c}9 \\
(33 \%)\end{array}$ & $\begin{array}{c}6 \\
(32 \%)\end{array}$ & $<0.0001$ & III, IV>II \\
\hline
\end{tabular}

Data is presented as median (minimum-maximum) or number of subjects (proportion). NC, non-asthmatic control; ICS, inhaled corticosteroid; ACT, Asthma Control Test; BDR, bronchodilator response;

* Number of subjects with at least one event in the past 8 weeks including visits to the emergency department, severe attacks, and hospitalizations.

\#Mantel-Haenszel chi-square test for Gender, Atopy, ICS treatment and Morbidity; and Kruskal-Wallis test for all other variables. Comparisons made between non-asthmatic control and Type I-IV categories

\$Bonferroni's multiple comparison adjustment was applied for paired comparison. 


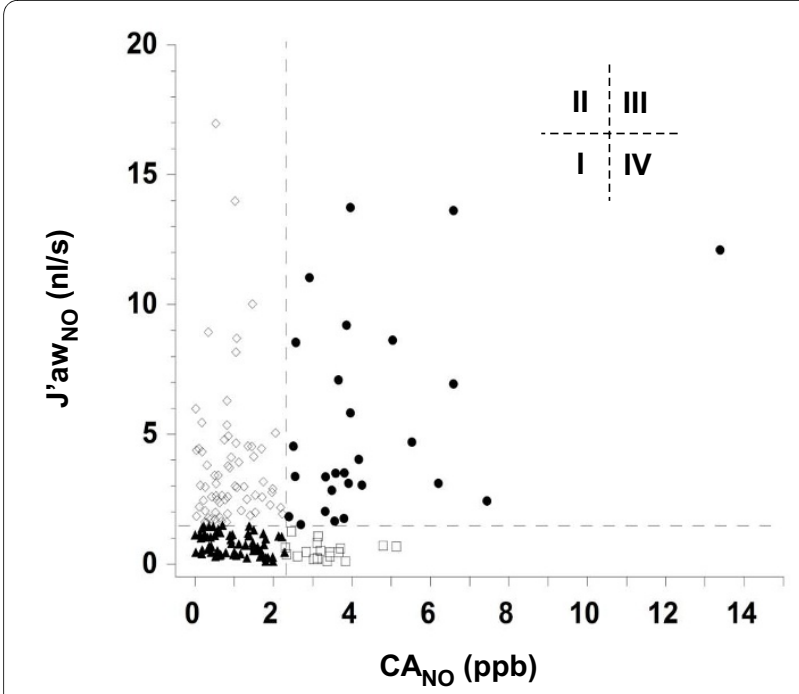

Figure 2 Exhaled nitric oxide (eNO) categories. Scatter plot between maximum proximal airway nitric oxide flux (J'aw ${ }_{N O}$ ) and distal airway/alveolar nitric oxide concentration $\left(\mathrm{CA}_{\mathrm{NO}}\right)$. When axial diffusion is considered, there is no correlation (Spearman rank, $r=-0.002$ ) between J'aw $\mathrm{NO}_{\mathrm{NO}}$ and $C \mathrm{~A}_{\mathrm{NO}}$. Asthmatic eNO categories based on thresholds for non-asthmatics J'aw $\mathrm{N}_{\mathrm{NO}}(\leq 1.5 \mathrm{nl} / \mathrm{s})$ and $\mathrm{CA}_{\mathrm{NO}}(\leq 2.3 \mathrm{ppb})$ : Type I (white triangle), normal J'aw $\mathrm{w}_{\mathrm{NO}}$ and normal $C A_{N O}$; Type II (white diamond), elevated J'aw ${ }_{N O}$ and normal $C A_{N O}$; Type III (white circle), elevated J'aw ${ }_{N O}$ and elevated $C A_{N O}$; and Type IV (white square), normal $J^{\prime} a w_{N O}$ and elevated $C_{N O}$.

non-asthmatic controls $[0.7(0.1-1.4) \mathrm{nl} / \mathrm{s}]$, Type I [0.7 $(0.1-1.5) \mathrm{nl} / \mathrm{s}]$ and Type IV [0.5 $(0.1-1.3) \mathrm{nl} / \mathrm{s}]$. There was no difference in $\mathrm{J}^{\prime} \mathrm{aw}_{\mathrm{NO}}$ between Type II and Type III. Details are summarized in Table 1.

Also, by design, $\mathrm{CA}_{\mathrm{NO}}$ was elevated in Type III [3.8 (2.413.4) ppb] and Type IV [3.1 (2.3-5.1) ppb] but not in nonasthmatic controls [1.5 (0.1-2.2) ppb], Type I [1.0 (0.0062.3) ppb] and Type II [0.8 (0.02-2.2) ppb] (Table 1). Furthermore, $\mathrm{CA}_{\mathrm{NO}}$ was found to be significantly $(\mathrm{p}=0.02)$ greater in Type III when compared to Type IV.

Since $\mathrm{FE}_{\mathrm{NO}, 50}$ was strongly correlated with $\mathrm{J}^{\prime} \mathrm{aw}_{\mathrm{NO}}$, $\mathrm{FE}_{\mathrm{NO}, 50}$ was significantly elevated in Type II [33.4 (17.7186.2) ppb] and Type III [49.9 (22.3-158.9) ppb] when compared to non-asthmatic controls [8.5 (2.2-15.3) ppb], Type I [9.4 (3.7-18.4) ppb] and Type IV [8.5 (4.6-16.9) $\mathrm{ppb}$ ] (Table 1). However, it was also found that $\mathrm{FE}_{\mathrm{NO}, 50}$ was significantly higher in Type III than Type II.

\section{Clinical patterns of eNO categories}

There were significant differences in $\mathrm{FEV}_{1} / \mathrm{FVC}$ ratio $(\mathrm{p}=$ 0.0016), where Type III [83.3 (72-100.1)] was lower than non-asthmatic controls [89.6 (84.5-102.1)] and Type I [89.4 (71.7-100)]. However, the median $\mathrm{FEV}_{1} / \mathrm{FVC}$ for Type III was within normal limits based on NHLBI/ NAEPP guidelines [1]. With regards to $\mathrm{FEV}_{1} / \mathrm{FVC}<80 \%$, there were approximately $4 \%, 18 \%, 22 \%$ and $0 \%$ for Types I to IV, respectively. There were no significant differences in $\mathrm{FEV}_{1}$ (\% predicted) amongst the four eNO categories and the non-asthmatic controls (Table 1).

The BDR was performed in 180 subjects and was found to be significantly different $(\mathrm{p}<0.0001$, Table 1$)$ amongst the five groups. The BDR in Type III was found to be significantly greater than non-asthmatic controls, Type I, and Type IV. Furthermore, the BDR in Type II was significantly greater than Type I.

The ACT score was significantly different $(\mathrm{p}<0.0001$, Table 1) amongst the eNO categories. The ACT scores in Type III and Type IV were significantly lower compared to Type I and Type II. Over $80 \%$ of Type I and Type II had an ACT score > 19, indicative of good asthma control; while $78 \%$ of Type III and $90 \%$ of Type IV had and ACT score $\leq 19$, indicative of poor asthma control.

The retrospective asthma risk factors (severe attacks, emergency department visits, and hospitalizations) were defined as any event during the last eight weeks (Table 1). There were significant differences amongst the eNO categories in the proportion of children with at least one asthma morbidity event ( $p<0.0001$, Table 1$)$. Multiple comparison adjustment demonstrated that the frequency of morbidity events was significantly greater in Type III and Type IV when compared to Type II.

\section{Discussion}

Our study has demonstrated that proximal airway $\left(\mathrm{J}^{\prime} \mathrm{aw}_{\mathrm{NO}}\right)$ and distal airway/alveolar $\mathrm{NO}\left(\mathrm{CA}_{\mathrm{NO}}\right)$ are not correlated in children with generally mild well-controlled asthma, thus allowing identification of four distinct eNO categories: Type I (normal nitric oxide), Type II (proximal airway predominant), Type III (proximal and distal airway predominant) and Type IV (distal airway predominant). Our main finding is that eNO categories with increased $\mathrm{CA}_{\mathrm{NO}}$ (i.e., Type III and Type IV) have much worse asthma control and morbidity (Table 1), despite different rates of ICS treatment, atopy, baseline spirometry, and BDR. Together, these findings support the presence of distinct inflammatory categories based on regional eNO, and suggest that distal $\mathrm{NO}\left(\mathrm{CA}_{\mathrm{NO}}\right)$ may be a more clinically sensitive, objective measure of asthma control compared to spirometry and proximal NO $\left(\mathrm{FE}_{\mathrm{NO}, 50}, \mathrm{~J}^{\prime} \mathrm{aw}_{\mathrm{NO}}\right)$.

\section{Inflammatory categories in asthma}

Traditionally, asthma has been grouped into two categories on the basis of etiology [41]: intrinsic and extrinsic. More recently, management guidelines have stratified asthma on the basis of severity [1]. However, the severity classification scheme does not consider the degree of airway inflammation, a factor which could improve clinical 
management $[42,43]$. There are only a few reports which utilize inflammatory patterns to characterize adult asthma [44-46] and none to the best of our knowledge, describe inflammatory categories in pediatric asthma. The idea of stratifying asthma based on inflammatory patterns was first presented by Wenzel et al. in 1999 [44]; severe asthmatics were divided into two subtypes based on the presence or absence of eosinophils in the bronchial biopsy specimen. In a 2006 study by Simpson et al. [45], the asthmatics were segregated into four inflammatory subtypes using induced sputum eosinophil and neutrophils counts. More recently, a 2009 study by Nadif et al. [46] demonstrated that blood eosinophil and neutrophil counts can be used to characterize adult asthma. However, these methods are more invasive in nature, more challenging to perform in children, and may not be ideally suited for the serial monitoring of asthmatic subjects. The current data suggest a relatively simple approach for non-invasively gauging information about the location and extent of inflammation in the asthmatic lung.

A general summary of the eNO categories is presented in Table 2. Well-controlled asthmatics generally appear in Type I and Type II categories. The common features between these categories are the absence of distal airway/ alveolar inflammation (low $\mathrm{CA}_{\mathrm{NO}}$ ) and normal baseline spirometry, despite differences in proximal $\mathrm{NO}\left(\mathrm{FE}_{\mathrm{NO}, 50}\right.$ and $\mathrm{J}^{\prime} \mathrm{aw}_{\mathrm{NO}}$ ), ICS treatment, atopy, and BDR. In contrast, poorly controlled asthmatics tend to fall into Type III and Type IV categories. The common features between these categories are the presence of distal airway/alveolar inflammation (high $\mathrm{CA}_{\mathrm{NO}}$ ), despite differences in proximal $\mathrm{NO}\left(\mathrm{FE}_{\mathrm{NO}, 50}\right.$ and $\left.\mathrm{J}^{\prime} \mathrm{aw}_{\mathrm{NO}}\right)$, ICS treatment, and BDR. Thus, distal inflammation, as indicated by an elevated $\mathrm{CA}_{\mathrm{NO}}$, appears to be the most robust predictor of asthma control in our group of relatively mild asthmatic children relative to traditional indices such as baseline spirometry and ICS therapy.

\section{Proximal versus distal airway inflammation}

Our observation that J'aw $\mathrm{NO}_{\mathrm{NO}}$ is strongly related to $\mathrm{FE}_{\mathrm{NO}, 50}$ indicates that an exhalation flow of $50 \mathrm{ml} / \mathrm{s}$ is low enough such that $\mathrm{FE}_{\mathrm{NO}, 50}$ is dominated by the proximal airway contribution, and partitioning the exhaled NO signal to estimate $\mathrm{J}^{\prime} \mathrm{aw}_{\mathrm{NO}}$ provides no additional information. Therefore, to characterize the inflammatory status of the proximal lung $\mathrm{FE}_{\mathrm{NO}, 50}$ is sufficient. However, even though the distal airway/alveolar concentration is a greater fraction of $\mathrm{FE}_{\mathrm{NO}}$ at higher flows, it remains very small, and $\mathrm{FE}_{\mathrm{NO}, 200}$ is only very weakly correlated with $\mathrm{CA}_{\mathrm{NO}}$; hence, the exhaled NO signal must be partitioned using a mathematical model to estimate the much smaller concentra- tion of $\mathrm{CA}_{\mathrm{NO}}$. Our observation that J'aw $\mathrm{NO}_{\mathrm{NO}}$ and $\mathrm{CA}_{\mathrm{NO}}$ are not correlated indicates they provide independent information regarding region specific NO. Of note is the confounding role of axial diffusion of NO which has been demonstrated in both healthy adults [37,47-49] and those with stable asthma) [50], but not in active asthma; if axial diffusion of NO is not considered in our data set, then a strong positive relationship $(\mathrm{r}=0.71)$ is observed between J'aw ${ }_{\mathrm{NO}}$ and $\mathrm{CA}_{\mathrm{NO}}$. In other words, a significant proximal airway source can contaminate the distal airway/alveolar region via axial (or "back") diffusion leading to an artificial elevation in $\mathrm{CA}_{\mathrm{NO}}$ and an erroneous positive correlation.

Proximal airway $\mathrm{NO}\left(\mathrm{FE}_{\mathrm{NO}, 50}\right.$ and $\left.\mathrm{J}^{\mathrm{a}} \mathrm{w}_{\mathrm{NO}}\right)$ has not been consistently associated with asthma control or a predictor of exacerbation [20-23]. One possibility for these findings is the confounding influences of ICS therapy and atopy, both of which strongly impact proximal airway NO [5,12,51-53]. For example, Paraskakis et. al [5] has demonstrated that $\mathrm{FE}_{\mathrm{NO}, 50}$ is no different between asthmatic and atopic non-asthmatic children. In our categories, $\mathrm{FE}_{\mathrm{NO}, 50}$ (and $\mathrm{J}^{\prime} \mathrm{aw} \mathrm{NO}_{\mathrm{NO}}$ ) progressively increased between Types I, II, and III $(9.4,33.4,49.9 \mathrm{ppb})$ as the proportion of subjects on ICS decreased $(79 \%, 56 \%, 18 \%)$, respectively. Type IV asthmatics do not follow this trend (79\% and $8.5 \mathrm{ppb}$, respectively). This observation is likely due to the peripheral (small airway/alveolar) nature of the inflammation which is not targeted by ICS.

In contrast, several different groups have reported clinically relevant observations regarding $\mathrm{CA}_{\mathrm{NO}}$ and asthma control [5,6,31-33]. For example, increased levels of $\mathrm{CA}_{\mathrm{NO}}$ have been reported in asthmatics with nocturnal symptoms [31], asthmatics with poor control (based on bronchodilator use) [5] or refractory to ICS treatment [32], as well as a predictor of asthma exacerbation [33]. These observations are consistent with our results of poor control in children with elevated $\mathrm{CA}_{\mathrm{NO}}$ (Types III and IV comprising $26 \%$ of our population). The association between poor asthma control and elevated $\mathrm{CA}_{\mathrm{NO}}$ is likely due to the presence of inflammation in the distal lung which can contribute to airflow limitation [2-4]. However, our data, as well as data in the literature, also demonstrate that that $\mathrm{CA}_{\mathrm{NO}}$ is much less dependent on confounding influences of ICS therapy and atopy compared to J'aw $\mathrm{NO}_{\mathrm{NO}}$ or $\mathrm{FE}_{\mathrm{NO}, 50}$. Paraskakis et. al [5] studied a group of more severe steroid-treated asthmatic children, and reported that $\mathrm{CA}_{\mathrm{NO}}$ was elevated in the children with poorly controlled asthma, but not in atopic non-asthmatic controls. Although our patient population represented relatively mild asthmatic children, we observed that the rate of atopy and ICS therapy differed amongst the eNO categories, but neither was related to asthma 
Table 2: Clinical patterns of the eNO categories

\begin{tabular}{|c|c|c|c|c|}
\hline & $\begin{array}{c}\text { Type I } \\
\text { Normal Nitric Oxide }\end{array}$ & $\begin{array}{c}\text { Type II } \\
\text { Proximal Airway } \\
\text { Predominant }\end{array}$ & $\begin{array}{c}\text { Type III } \\
\text { Proximal and Distal } \\
\text { Airway Predominant }\end{array}$ & $\begin{array}{c}\text { Type IV } \\
\text { Distal Airway } \\
\text { Predominant }\end{array}$ \\
\hline \multicolumn{5}{|c|}{ EXHALED NITRIC OXIDE } \\
\hline $\mathrm{J}^{\prime} \mathrm{aw}_{\mathrm{NO}}(\mathrm{nl} / \mathrm{s})$ & $<1.5$ & $\geq 1.5$ & $\geq 1.5$ & $<1.5$ \\
\hline$C A_{N O}(p p b)$ & $<2.3$ & $<2.3$ & $\geq 2.3$ & $\geq 2.3$ \\
\hline $\mathrm{FE}_{\mathrm{NO}, 50}(\mathrm{ppb})^{\#}$ & $\cdot$ & $\ldots$ & ... & - \\
\hline
\end{tabular}

THERAPY AND ATOPY

\begin{tabular}{ccccc}
\hline Atopy & $\ldots$ & $\ldots$. & $\ldots$ & $\ldots$ \\
\hline ICS treatment & $\ldots .$. & $\ldots$ & $\ldots$ & $\ldots$ \\
\hline
\end{tabular}

\begin{tabular}{ccccc}
\hline LUNG FUNCTION & & & \\
\hline Abnormal Spirometry & $\cdot$ & $\cdot$ & & \\
\hline BDR $>10 \%$ & $\cdot$ &. & $\ldots$ & $\cdot$ \\
\hline
\end{tabular}

\section{CONTROL and RISK}

\begin{tabular}{ccccc}
\hline ACT $\leq 19$ &. &... & & \\
\hline Morbidity* &. &.. & \\
\hline
\end{tabular}

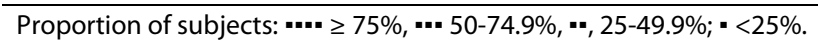

"Abnormal $\mathrm{FE}_{\mathrm{NO}, 50}$ is based on the upper limit of the non-asthmatic, non-atopic controls ( $\geq 16 \mathrm{ppb}$ ).

Abnormal spirometry: $\mathrm{FEV}_{1} \%$ predicted $<80 \%$ or FVC $\%$ predicted $<80 \%$ or $\mathrm{FEV}_{1} / \mathrm{FVC}<80 \%$.

Asthma control test (ACT) $\leq 19$ is indicative of poor asthma control.

* Proportion of subjects with at least one event in the past 8 weeks including visits to the emergency department, severe attacks, and hospitalizations.

control (e.g., rate of atopy was highest in the well-controlled Type II and rate of ICS highest in poorly controlled Type IV and well-controlled Type I).

Although ICS therapy does not appear to impact $\mathrm{CA}_{\mathrm{NO}}$, nor improve control in asthmatic children with elevated $\mathrm{CA}_{\mathrm{NO}}$, reports in the literature demonstrate that $\mathrm{CA}_{\mathrm{NO}}$ and asthma control do respond to systemic medications, namely oral corticosteroids [32,54] and leukotriene receptor antagonists [55]. Together, these results suggest that proximal airway and distal airway/alveolar $\mathrm{NO}$ respond differently to treatment, and thus may be of clinical utility [29]. However, well-designed longitudinal studies are necessary to determine appropriate therapeutic options for achieving asthma control in children with elevated $\mathrm{CA}_{\mathrm{NO}}$.

\section{Study limitations}

Our pediatric population was predominately Hispanic (95\%). Ethnicity may impact response to asthma medications due to genetic differences in cellular receptors [56], and thus our results may not apply to other ethnic groups. Approximately $10 \%$ of the asthmatic subjects did not fit the two compartment model of NO exchange in the lungs. However, the model was successfully applied in all of the non-asthmatic subjects. These results are similar to the findings of Paraskakis et al. [5], and may be related to heterogeneous ventilation and inflammation patterns in some asthmatic subjects [57]. Finally, we enrolled subjects independent of inhaled corticosteroid use which allowed us to evaluate the differential effect of 
ICS therapy on proximal and distal eNO and the relationship to asthma control.

\section{Conclusions}

In summary, we propose a novel method for non-invasively categorizing asthma based on region specific NO parameters J'aw ${ }_{\mathrm{NO}}$ and $\mathrm{CA}_{\mathrm{NO}}$. We have shown that J'aw ${ }_{\mathrm{NO}}$ and $\mathrm{CA}_{\mathrm{NO}}$ can be selectively elevated in asthma, permitting identification of four eNO categories with distinct clinical patterns. The categories characterized by increased $\mathrm{CA}_{\mathrm{NO}}$ (Types III and IV) have much worse (but similar to each other) asthma control and morbidity, despite significantly different rates of ICS therapy, atopy, baseline spirometry and BDR. Hence, our preliminary observations in a mobile asthma clinic setting, suggest that categorizing asthma using proximal and distal NO may be clinically useful, both in terms of feasibility and management of asthma control. For example, our data suggest that Type III and Type IV asthmatics may not achieve good asthma control with standard ICS therapy. Future studies must address the dynamic (i.e., longitudinal) nature of the categories with regards to therapy and disease progression, the relationship to other inflammatory indices such as cells in the sputum, blood or bronchial biopsy, whether this categorization strategy is relevant in maintaining asthma control and reducing asthma morbidity, and the role of axial diffusion of NO in active asthma. Nonetheless, these results suggest that not one (i.e., $\mathrm{FE}_{\mathrm{NO}, 50}$ ), but all aspects of eNO may be important in the management of asthma, and that partitioning eNO to determine $\mathrm{CA}_{\mathrm{NO}}$ may significantly improve the clinical relevance of the eNO signal.

\section{Competing interests}

The authors declare that they have no competing interests.

\begin{abstract}
Authors' contributions
JP assisted in the design of the experiment, data collection , and the writing the manuscript. RT assisted in the data analysis and interpretation. S-YL performed the statistical analysis, and assisted in the interpretation of the data and the writing of specific sections of the manuscript. OG assisted in the collection and interpretation of the data. AA assisted in the data collection through the completion of the IRB approval, and also assisted in the interpretation of the data. SPG and SCG conceived of the orginal concept and experimental design, and assisted in the data interpretation and writing of the manuscript. All authors read and approved the final manuscript.
\end{abstract}

\section{Acknowledgements}

This work was supported by a grant from the National Institutes of Health (R01 HL070645) and the Children's Hospital of Orange County.

\footnotetext{
Author Details

'Department of Biomedical Engineering, 2420 Engineering Tower, University of California, Irvine, Irvine, CA 92697, USA, 2Institute for Clinical Translational Science, 1115 Hewitt Hall, University of California, Irvine, Irvine, CA 92697, USA, ${ }^{3}$ Children's Hospital of Orange County, 804 W. Collins, Orange, CA 92868, USA, 4Department of Medicine, 2420 Engineering Tower, University of California, Irvine, Irvine, CA 92697, USA and 5Department of Chemical Engineering and Materials Science, 2420 Engineering Tower, University of California, Irvine, Irvine, CA 92697, USA
}

Received: 10 December 2009 Accepted: 28 April 2010

Published: 28 April 2010

\section{References}

1. Expert Panel Report 3 (EPR-3): Guidelines for the Diagnosis and Management of Asthma-Summary Report 2007. J Allergy Clin Immunol 2007, 120(5 Suppl):S94-138.

2. Kraft M, Djukanovic R, Wilson S, Holgate ST, Martin RJ: Alveolar tissue inflammation in asthma. Am J Respir Crit Care Med 1996, 154(5):1505-1510.

3. Sutherland ER, Martin RJ, Bowler RP, Zhang Y, Rex MD, Kraft M: Physiologic correlates of distal lung inflammation in asthma. J Allergy Clin Immunol 2004, 113(6):1046-1050.

4. Payne DN, Qiu Y, Zhu J, Peachey L, Scallan M, Bush A, Jeffery PK: Airway inflammation in children with difficult asthma: relationships with airflow limitation and persistent symptoms. Thorax 2004, 59(10):862-869.

5. Paraskakis E, Brindicci C, Fleming L, Krol R, Kharitonov SA, Wilson NM, Barnes PJ, Bush A: Measurement of bronchial and alveolar nitric oxide production in normal children and children with asthma. Am J Respir Crit Care Med 2006, 174(3):260-267.

6. Mahut B, Delacourt C, Zerah-Lancner F, De Blic J, Harf A, Delclaux C: Increase in alveolar nitric oxide in the presence of symptoms in childhood asthma. Chest 2004, 125(3):1012-1018.

7. Wenzel SE: Asthma: defining of the persistent adult phenotypes. Lancet 2006, 368(9537):804-813.

8. Silkoff PE, McClean PA, Slutsky AS, Furlott HG, Hoffstein E, Wakita S, Chapman KR, Szalai JP, Zamel N: Marked flow-dependence of exhaled nitric oxide using a new technique to exclude nasal nitric oxide. Am J Respir Crit Care Med 1997, 155(1):260-267.

9. Tsoukias NM, Tannous Z, Wilson AF, George SC: Single-exhalation profiles of $\mathrm{NO}$ and $\mathrm{CO} 2$ in humans: effect of dynamically changing flow rate. J Appl Physiol 1998, 85(2):642-652.

10. ATS/ERS recommendations for standardized procedures for the online and offline measurement of exhaled lower respiratory nitric oxide and nasal nitric oxide, 2005. Am J Respir Crit Care Med 2005, 171(8):912-930.

11. Alving K, Weitzberg E, Lundberg JM: Increased amount of nitric oxide in exhaled air of asthmatics. Eur Respir J 1993, 6(9):1368-1370.

12. Kharitonov SA, Yates DH, Chung KF, Barnes PJ: Changes in the dose of inhaled steroid affect exhaled nitric oxide levels in asthmatic patients. Eur Respir J 1996, 9(2):196-201.

13. Steerenberg PA, Janssen NA, de Meer G, Fischer PH, Nierkens S, van Loveren H, Opperhuizen A, Brunekreef B, van Amsterdam JG: Relationship between exhaled NO, respiratory symptoms, lung function, bronchial hyperresponsiveness, and blood eosinophilia in school children. Thorax 2003, 58(3):242-245.

14. Thomas PS, Gibson PG, Wang H, Shah S, Henry RL: The relationship of exhaled nitric oxide to airway inflammation and responsiveness in children. J Asthma 2005, 42(4):291-295.

15. Sacco O, Sale R, Silvestri M, Serpero L, Sabatini F, Raynal ME, Biraghi M, Rossi GA: Total and allergen-specific IgE levels in serum reflect blood eosinophilia and fractional exhaled nitric oxide concentrations but not pulmonary functions in allergic asthmatic children sensitized to house dust mites. Pediatr Allergy Immunol 2003, 14(6):475-481.

16. Strunk RC, Szefler SJ, Phillips BR, Zeiger RS, Chinchilli VM, Larsen G, Hodgdon K, Morgan W, Sorkness CA, Lemanske RF Jr: Relationship of exhaled nitric oxide to clinical and inflammatory markers of persistent asthma in children. J Allergy Clin Immunol 2003, 112(5):883-892.

17. Jatakanon A, Lim S, Kharitonov SA, Chung KF, Barnes PJ: Correlation between exhaled nitric oxide, sputum eosinophils, and methacholine responsiveness in patients with mild asthma. Thorax 1998, 53(2):91-95.

18. Langley SJ, Goldthorpe S, Custovic A, Woodcock A: Relationship among pulmonary function, bronchial reactivity, and exhaled nitric oxide in a large group of asthmatic patients. Ann Allergy Asthma Immunol 2003, 91(4):398-404

19. Berkman N, Avital A, Breuer R, Bardach E, Springer C, Godfrey S: Exhaled nitric oxide in the diagnosis of asthma: comparison with bronchial provocation tests. Thorax 2005, 60(5):383-388

20. Leuppi JD, Salome CM, Jenkins CR, Anderson SD, Xuan W, Marks GB, Koskela H, Brannan JD, Freed R, Andersson M, et al:: Predictive markers of 
asthma exacerbation during stepwise dose reduction of inhaled corticosteroids. Am J Respir Crit Care Med 2001, 163(2):406-412.

21. Smith AD, Cowan JO, Brassett KP, Herbison GP, Taylor DR: Use of exhaled nitric oxide measurements to guide treatment in chronic asthma. $N$ Engl J Med 2005, 352(21):2163-2173.

22. Zacharasiewicz A, Wilson N, Lex C, Erin EM, Li AM, Hansel T, Khan M, Bush A: Clinical use of noninvasive measurements of airway inflammation in steroid reduction in children. Am J Respir Crit Care Med 2005, 171(10):1077-1082

23. Shaw DE, Berry MA, Thomas M, Green RH, Brightling CE, Wardlaw AJ, Pavord ID: The use of exhaled nitric oxide to guide asthma management: a randomized controlled trial. Am J Respir Crit Care Med 2007, 176(3):231-237.

24. Fritsch M, Uxa S, Horak F Jr, Putschoegl B, Dehlink E, Szepfalusi Z, Frischer $\mathrm{T}$ : Exhaled nitric oxide in the management of childhood asthma: $A$ prospective 6-months study. Pediatr Pulmonol 2006, 41(9):855-862.

25. Pijnenburg MW, Bakker EM, Hop WC, De Jongste JC: Titrating steroids on exhaled nitric oxide in children with asthma: a randomized controlled trial. Am J Respir Crit Care Med 2005, 172(7):831-836.

26. Szefler SJ, Mitchell H, Sorkness CA, Gergen PJ, O'Connor GT, Morgan WJ, Kattan M, Pongracic JA, Teach SJ, Bloomberg GR, et al:: Management of asthma based on exhaled nitric oxide in addition to guideline-based treatment for inner-city adolescents and young adults: a randomised controlled trial. Lancet 2008, 372(9643):1065-1072.

27. Jones SL, Kittelson J, Cowan JO, Flannery EM, Hancox RJ, McLachlan CR, Taylor DR: The predictive value of exhaled nitric oxide measurements in assessing changes in asthma control. Am J Respir Crit Care Med 2001, 164(5):738-743

28. Gibson PG: Using fractional exhaled nitric oxide to guide asthma therapy: design and methodological issues for ASthma TReatment ALgorithm studies. Clin Exp Allergy 2009, 39(4):478-490.

29. Puckett JL, George SC: Partitioned exhaled nitric oxide to non-invasively assess asthma. Respir Physio/ Neurobiol 2008, 163(1-3):166-177.

30. Lehtimaki L, Turjanmaa V, Kankaanranta H, Saarelainen S, Hahtola P, Moilanen E: Increased bronchial nitric oxide production in patients with asthma measured with a novel method of different exhalation flow rates. Ann Med 2000, 32(6):417-423.

31. Lehtimaki L, Kankaanranta H, Saarelainen S, Turjanmaa V, Moilanen E: Increased alveolar nitric oxide concentration in asthmatic patients with nocturnal symptoms. Eur Respir J 2002, 20(4):841-845.

32. Berry M, Hargadon B, Morgan A, Shelley M, Richter J, Shaw D, Green RH, Brightling C, Wardlaw AJ, Pavord ID: Alveolar nitric oxide in adults with asthma: evidence of distal lung inflammation in refractory asthma. Eur Respir J 2005, 25(6):986-991.

33. Gelb AF, Flynn Taylor C, Shinar CM, Gutierrez C, Zamel N: Role of spirometry and exhaled nitric oxide to predict exacerbations in treated asthmatics. Chest 2006, 129(6):1492-1499.

34. Liu AH, Zeiger R, Sorkness C, Mahr T, Ostrom N, Burgess S, Rosenzweig JC, Manjunath R: Development and cross-sectional validation of the Childhood Asthma Control Test. JAllergy Clin Immunol 2007 , 119(4):817-825.

35. Nathan RA, Sorkness CA, Kosinski M, Schatz M, Li JT, Marcus P, Murray JJ, Pendergraft TB: Development of the asthma control test: a survey for assessing asthma control. J Allergy Clin Immunol 2004, 113(1):59-65.

36. Lung function testing: selection of reference values and interpretative strategies. American Thoracic Society. Am Rev Respir Dis 1991, 144(5):1202-1218

37. Condorelli P, Shin HW, Aledia AS, Silkoff PE, George SC: A simple technique to characterize proximal and peripheral nitric oxide exchange using constant flow exhalations and an axial diffusion model. J Appl Physiol 2007, 102(1):417-425.

38. George SC, Hogman M, Permutt S, Silkoff PE: Modeling pulmonary nitric oxide exchange. J Appl Physiol 2004, 96(3):831-839.

39. Tsoukias NM, George SC: A two-compartment model of pulmonary nitric oxide exchange dynamics. J App/ Physio/ 1998, 85(2):653-666.

40. Sepponen A, Lehtimaki L, Huhtala H, Kaila M, Kankaanranta H, Moilanen E: Alveolar and bronchial nitric oxide output in healthy children. Pediatr Pulmonol 2008, 43(12):1242-1248.

41. Rackemann F: A clinical classification of asthma. Am J Med Sci 1921, 12:802-803

42. Green RH, Brightling CE, McKenna S, Hargadon B, Parker D, Bradding P Wardlaw AJ, Pavord ID: Asthma exacerbations and sputum eosinophil counts: a randomised controlled trial. Lancet 2002, 360(9347):1715-1721

43. Jayaram L, Pizzichini MM, Cook RJ, Boulet LP, Lemiere C, Pizzichini E, Cartier A, Hussack P, Goldsmith CH, Laviolette M, et al: Determining asthma treatment by monitoring sputum cell counts: effect on exacerbations. Eur Respir J 2006, 27(3):483-494.

44. Wenzel SE, Schwartz LB, Langmack EL, Halliday JL, Trudeau JB, Gibbs RL, Chu HW: Evidence that severe asthma can be divided pathologically into two inflammatory subtypes with distinct physiologic and clinical characteristics. Am J Respir Crit Care Med 1999, 160(3):1001-1008.

45. Simpson JL, Scott R, Boyle MJ, Gibson PG: Inflammatory subtypes in asthma: assessment and identification using induced sputum. Respirology 2006, 11(1):54-61.

46. Nadif R, Siroux V, Oryszczyn MP, Ravault C, Pison C, Pin I, Kauffmann F: Heterogeneity of asthma according to blood inflammatory patterns. Thorax 2009, 64(5):374-80

47. Shin H-W, Condorelli P, George SC: Examining axial diffusion of nitric oxide in the lungs using heliox and breath hold. J App/ Physio/ 2006, 100(2):623-630

48. Shin H-W, Condorelli P, Rose-Gottron CM, Cooper DM, George SC: Probing the impact of axial diffusion on nitric oxide exchange dynamics with heliox. J Appl Physio/ 2004, 97(3):874-882.

49. Shin H-W, George SC: Impact of axial diffusion on nitric oxide exchange in the lungs. J Appl Physiol 2002, 93(6):2070-2080.

50. Kerckx Y, Michils A, Van Muylem A: Airway contribution to alveolar nitric oxide in healthy subjects and stable asthma patients. $J$ Appl Physiol 2008, 104(4):918-924.

51. Jouaville LF, Annesi-Maesano I, Nguyen LT, Bocage AS, Bedu M, Caillaud D: Interrelationships among asthma, atopy, rhinitis and exhaled nitric oxide in a population-based sample of children. Clin Exp Allergy 2003, 33(11):1506-1511.

52. Lehtimaki L, Kankaanranta H, Saarelainen S, Turjanmaa V, Moilanen E: Inhaled fluticasone decreases bronchial but not alveolar nitric oxide output in asthma. Eur Respir J 2001, 18(4):635-639.

53. Moody A, Fergusson W, Wells A, Bartley J, Kolbe J: Increased nitric oxide production in the respiratory tract in asymptomatic pacific islanders: an association with skin prick reactivity to house dust mite. J Allergy Clin Immunol 2000, 105(5):895-899.

54. Gelb AF, Taylor CF, Nussbaum E, Gutierrez C, Schein A, Shinar CM, Schein MJ, Epstein JD, Zamel N: Alveolar and Airway Sites of Nitric Oxide Inflammation in Treated Asthmatics. Am J Respir Crit Care Med 2004, 170:737-741.

55. Fritscher LG, Rodrigues MT, Zamel N, Chapman KR: The effect of montelukast on exhaled nitric oxide of alveolar and bronchial origin in inhaled corticosteroid-treated asthma. Respir Med 2009, 103(2):296-300.

56. Lima JJ, Blake KV, Tantisira KG, Weiss ST: Pharmacogenetics of asthma. Curr Opin Pulm Med 2009, 15(1):57-62.

57. Suresh V, Shelley DA, Shin HW, George SC: Effect of heterogeneous ventilation and nitric oxide production on exhaled nitric oxide profiles. J Appl Physiol 2008, 104(6):1743-1752.

doi: $10.1186 / 1465-9921-11-47$

Cite this article as: Puckett et al., Clinical patterns in asthma based on proximal and distal airway nitric oxide categories Respiratory Research 2010, 11:47

\section{Submit your next manuscript to BioMed Central and take full advantage of:}

- Convenient online submission

- Thorough peer review

- No space constraints or color figure charges

- Immediate publication on acceptance

- Inclusion in PubMed, CAS, Scopus and Google Scholar

- Research which is freely available for redistribution 